\title{
Pulmonary resection for NSCLC in octogenarians: a single center experience
}

\author{
S Di Russo, A Mani", L Guetti, P Camplese, G Cipollone, T larussi, F Mucilli \\ From XXIII Annual Meeting of the Italian Society of Geriatric Surgery \\ Lecce, Italy. 2-4 December 2010
}

\section{Background}

Lung cancer is the second leading cancer death among octogenarians $\left[{ }^{1}\right]$ and in particular NSCLC accounts for more than $90 \%$ of all lung cancers. Since life expectancy is improving, lung cancers are observed among octogenarians people more often. Surgical resection remains the treatment of choice for early stage lung cancer ${ }^{2}$. The authors report the outcomes of pulmonary resection for NSCLC in octogenarians.

\section{Materials and methods}

We reviewed our center experience in elderly patients between 1999 and 2009 and reported perioperative mortality and morbidity. Thirty patients older than 80 years underwent surgical resection for NSCLC. Among these 19 lobectomies, 1 sleeve-lobectomy, 2 bilobectomies, 6 segmentectomies and 2 wedge resections were performed.

\section{Results}

Post-operative non fatal complication occurred in 6 patients (20\%): atrial fibrillation in 3 patients (10\%), blood loss in 2 patients $(6.6 \%)$, renal failure in 2 patients (6.6\%), transitory cardiac arrhythmia in 1 patient (3\%) and respiratory failure in 1 patient (3\%). There was 1 post-operative death (3\%).

\section{Conclusions}

The advances in preoperative and postoperative care and surgical technique allow a larger number of curative resections in octogenarians patients $\left[{ }^{2}\right]$. Therefore age is not an absolute contraindication for NSCLC surgical treatment but pre-operative study is mandatory. It

\footnotetext{
* Correspondence: aleksandermani@gmail.com
Department of Surgical Sciences - Unit of Surgical Clinic, University of Chieti

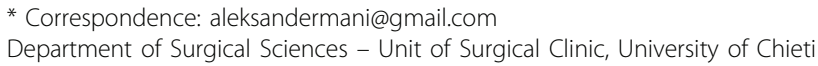
"G. D'Annunzio", Chieti, Italy
}

(C) 2011 Di Russo et al; licensee BioMed Central Ltd. This is an open access article distributed under the terms of the Creative Commons

highlights comorbidity that can badly influence the post-operatory outcome and the survival.

Published: 24 August 2011

\section{References}

1. Port $\lrcorner$, Kent M: Surgical resection for lung cancer in Otogenarian. Chest 2004, 126:733-738

2. Voltolini $L$, Rapicetta $C$ : Short-and long-term results of lung resection for cancer in Octogenarians. Asian Cardiovasc Thorac Ann 2009, 17:147-152.

doi:10.1186/1471-2318-11-S1-A11

Cite this article as: Di Russo et al:: Pulmonary resection for NSCLC in octogenarians: a single center experience. BMC Geriatrics 2011 11(Suppl 1):A11.

Submit your next manuscript to BioMed Central and take full advantage of:

- Convenient online submission

- Thorough peer review

- No space constraints or color figure charges

- Immediate publication on acceptance

- Inclusion in PubMed, CAS, Scopus and Google Scholar

- Research which is freely available for redistribution 